\title{
Characteristics of Moslem Families Economy Based on Maqashid Sharia Perspective
}

\author{
Faris Shalahuddin Zakiy ${ }^{1 *}$, Ahmad Muhtadi Ridwan², \\ Achmad Sani Supriyanto ${ }^{3}$ \\ ${ }^{1}$ UIN Walisongo Semarang \\ ${ }^{2}$ Faculty of Economics and Business, UIN Maulana Malik \\ Ibrahim Malang \\ ${ }^{3}$ UIN Maulana Malik Ibrahim Malang \\ email: farisshalahuddinzakiy@walisongo.ac.id, \\ read_one_feuinmlg@yahoo.co.id achmad_sani72@yahoo.com
}

\begin{abstract}
Modern lifestyle has interfered principles of moslem families. This era tries to define attitude, wealth value, and social position of individuals in society. It might become a doctrine, patent product, challenge or threat. The objective of this research is to elaborate the Islamic characteristics within the economy of moslem families and also implementation of Maqashid Sharia in the economy of moslem families. This research exerts case-study, by determining selected informants from the community of moslem small entrepreneurs in Malang. The findings show that the moslem families consider faith (iman) as basic foundation of economy. They also hold on to character perfection that is based on akhlaqul karimah, lawfulness and wholesomeness, priority scale as expenditure reference, moderation as absolute standardization and responsibility of woman's wealth proprietary. Internalization of Islamic economy principles in the moslem families economy includes the statement that working as a form of ikhtiar and worship, expenditure as material and spiritual distribution of wealth, savings as urgent post in the future, and wealth as instrument to serve to Allah. Finally, it is important to regard Maqashid Sharia as a standard of Muslim action in economy.
\end{abstract}

Keyword: Characteristics, Islamic Economics Rules, Moslem Families Economy, Maqashid Sharia 


\section{INTRODUCTION}

Rampant modern lifestyle in Indonesia has been started from history of economic globalization and capitalism which is indicated by the hegemony of food, fun, fashion, and thought (Mustofa, 2008). This hegemony is verified by the presence of modern shopping center, freelance industry, fashion industry, beauty industry, gossip industry, real estate, luxury goods advertisement, import brand-minded, fast food, hand phone, and some sort of lifestyle showed in advertisement industry and television (Hendrariningrum, et al, 2008). This era defines attitude, riches value, and social position of each individual in society (Chaney, 2004). It might even be a doctrine, patent product, challenge and at the worst threat to the moslem families (Mustofa, 2008).

Modern age is also an era of changing value on the society coming from the Western culture, and then affects to the imbalance between this ideology and religion ideology. The culture of individualism, consumerism, hedonism, and materialism as part of Western ideology (Mustofa, 2008) which are based on the prideful and luxurious life, prestige, show off consumption, and profit oriented aim to shift character and economic principle on the economy of moslem families (Alfitri, 2007).

Having good character and principles on the economy of moslem families is actually not enough to cope with the impact of nowadays modern lifestyle. It needs more effort on internalization of Divinely doctrine into the character and economic principles. This statement is in line with Syahatah. He asserted that the economy of moslem family means economic principles and rules which applied in the scope of family that are based on Qur'an, Hadits, Scholars' opinion, and Islamic Studies related to the economy in order to implement Maqashid Sharia and comply with material and spiritual need of family which is certainly on proportional scale (Syahatah, 1998).

Moslem families might have several different professions, and yet have single uniqueness in business world. This is called entrepreneur. A successful businessman is indicated by the 
luxurious lifestyle, glamour, excessive pretension and ambition towards riches and luxuries. Even more, some scholars regard the business world as the biggest world affair which would deliver bad impact for human to be always busy with their affairs and then neglect to remember Allah. Malang is one of cities that the researcher wants to highlight in this research discussion, since this city has been a metropolitan city with so many modern shopping centers in town and modern lifestyle of society. It indicates that the effect of lifestyle modernization is quite significant to the economy of moslem families.

This research aims to examine and to clarify in depth the economy of moslem families on the small moslementrepreneurship of Malang which covers to the characteristics and principles of Islamic economy and realization of Maqashid Sharia principle in the economy of moslem families to cope with the era of modern lifestyle.

\section{LITERATURE REVIEW Economy of Moslem Families}

Economy of moslem familes is a principle and rule of family economy which is based on Islamic norms. The norms aim to fulfill both spiritual and physical need of the family member (Syahatah, 1998). This definition implies several indicators for the economy of moslem family: 1) the economy of moslem family is considered as collection of principle and rule that are based on the Islamic norms from Qur'an, Hadits, and Scholars' opinion. 2) The system of Islamic economy for the family is part of Islamic economy system in the state. 3) The economic system of moslem families includes characters, incomes, expenditures, savings, and ownership, which have purpose to realize the Sharia principles to the family member (Syahatah, 1998).

\section{Characteristics of Moslem Families' Economy}

To keep balance between the spiritual and material need, it needs a number of characteristics below within the economy of moslem families: 


\section{Value of Faith (Iman)}

Value of Iman is regarded as a base of moslem families' economy. Then, it is a must to the member of family to maintain the family income and expenditure from the matters that are banned in Sharia principles. Moreover, the moslem families should regard the wealth as medium of worshiping Allah. It is written in the Qur'an (QS. Al-Hadid: 7 dan QS. An-Nahl: 71) and Hadits which asserted that on the Jugdgement Day, man would be asked about four questions; the question of wealth ownership, from where the wealth is obtained and to whom the wealth is given (Narrated by Tirmidzi).

\section{Value of Character (Akhlaq)}

Value of akhlaq refers to trusteeship, honesty, contentment, and patient. They are the main characters needed in the economy of moslem families. One Hadits said that for the family with faith and good character, Allah will shower them with prosperities and blessings (Narrated by Bukhari and Muslim). It is in line with firman Allah (QS. At-Taubah: 119 dan QS. An-Nisa: 58).

\section{Value of Lawfulness and Wholesomeness}

Income and expenditure of a family must be clear from every badness and illicit in life of moslem. As it has been written in QS. An-Nahl: 114, QS. Al-Baqarah: 172, QS. Al-Baqarah 173 dan QS. Al-Maidah: 90.

\section{Priority Scale}

Scale of priority is allocated for expenditure, investment, and production. It is good to give priority to the important and essential needs of family, then hajiyat and tahsiniyat needs. This priority scale is allocated to realize the principle of Maqashid Sharia, which means to take care of religion, soul, mind, wealth, and generation.

\section{Balance}

To have a balanced income and expenditure aims to stabilize the balance of family's budget. However, this balance does not 
mean to be too economical, which seems to be stingy and miserly. This balance should be proportional and be able to fulfill the spiritual and material needs of family. This statement is explained in the Qur'an (QS. Al-Furqon: 67 dan QS. Al-Qashas: 77) and Hadits that human should eat and dress up on their own course, but do not be over (Narrated by Bukhari and Muslim). The other Hadits said that Allah will shower the blessings to the human who work in lawful manners, spend money in thrift, and save money for the hardest time (Narrated by Bukhari and Muslim).

\section{Value of Responsibility and Honor to the Wealth Ownership}

Islamic principles teach human to honor and own the responsibility especially for the man to work and earn money, and also to honor wealth ownership and woman. Every man and woman has each right over this matter as it has determined in QS. An-Nisa: 32 dan QS. An-Nisa 34.

\section{Principles of Islamic Economy on the Economy of Moslem Families \\ Principle of To Make Effort and Work}

According to Ibn Khaldun, income refers to the value of work. The meaning of income differs from the term blessing. Human works in order to earn money. If this income delivers profit to fulfill the needs, then this income is called blessing (Khaldun, 2013).

Income means the result of doing work and effort. Independent work means every activity that is dynamic and has purpose to comply with the spiritual and physical needs (Aziz, 2013). Therefore, to work is an obligation that mentioned in Islam. In Islamic principles, work motivation is not only based on will to earn money, but also activity of worship, economic aspect, and delivering profit for other human (Diana, 2011).

Islam has regulated human to work and earn money. As for, the rules that are obliged for the moslem families to work and make effort, they are (Syahatah, 1998): 1) To work is man's duty, 2) Wife has the right to work under certain circumstances (upon the boundaries determined by Sharia) to help the family economy, 
3) To keep balance between work and family rights, 4) To earn lawful money and have kind of lawful profession and work, also to work in lawful manners.

\section{Principle of Expenditure}

From the consumption manner proposed by Salman AlFarisi, it is concluded that the sort expenditure that is obliged to the moslem families are: 1) To expend consumption to fulfill the family needs, either material or spiritual needs. 2) To expend donation for goodness as realization of social function of wealth, this donation is mandatory (zakat) and voluntarily (infaq, shadaqoh, and other forms of donation). 3) To expend investment to develop wealth to the profitable business sectors, indeed in lawful manners (Djalaluddin, 2018).

\section{Principle of Saving}

Other than to expend consumption, donation and investment, Islam also encourages moslem families to save money. There are verses that banned the practice of excessive expenditure (QS. Al-Isra 26-27 dan 29). These two verses become the base argumentation over this principle. Independent saving means to save some fund to be utilized in the future which come from the rest of income and expenditure (Djalaluddin, 2018).

\section{Principle of Ownership}

Ownership is significant to be considered as it could encourage and boost the work motivation and productivity to live prosperously; even it becomes a base of transaction. By the ownership, the families are able to have consumption, investment, production, and distribution. In Islamic view, wealth is tentative goods. Therefore, the moslem families regard the ownership as a instrument to boost the spirit of worship to Allah. Definitely, the wealth is utilized in good things (Syahatah, 1998). Then, it is also important to separate the wealth ownership of husband and wife. Islam gives right to the woman as ownership right, entrepreneurial right, and hereditary right. For this, the man is prohibited to take over the wife's wealth, except it is used in good 
deeds. The inheritance is one of ownership source. The inheritance is asserted to be ownership transfer from one generation to the next one (Syahatah, 1998).

\section{Maqashid Sharia}

Maqashid Sharia comprises of two words, maqashid and Sharia. The term of maqashid comes from the plural form of the word maqsud which means purpose and intention. Terminologically, the term of Sharia means a path to spring. This path head to the spring that means that this path would heald human to the principal base of life (Shidiq, 2009). Maqashid Sharia refers to comply with the human needs by the manner of realizing common good and avoiding harm from the human. Generally, common good is able to achieve in two manners (Syarifuddin, 2008): 1). To realize benefit, good deed, and prosperity to the human, it is called as the term of jalb al-manafi'. This benefit could either feel about directly or indirectly in the future. 2) To avoid or prevent damage and bad deed, which is called as dar' $u$ al-mafasid. As for, to put the standardization to determine whether this deed categorized as common good or harm is basic needs for human being life (Muslimin, 2012).

\section{Religion Preservation}

In this matter, the primary, secondary, and tertiary need of moslem families that have to be complied with is to take care of religion, association, and moral. All aspects of economic activity in family, like to earn money, to expend family's need, to do investment, to save money and have ownership should be based on the doctrine of ilahiyah, lawfulness and wholesomeness, and to prevent the families from illicit and doubtful things (Hafidhuddin, 2007).

\section{Soul Preservation}

To maintain the existence of families' viability, there are number of needs that should be fulfilled by the families from the aspect of dharuriyat, hajiyat, and tahsiniyat needs. From the dharuriyat aspect, family should fulfill the need of clothing, house, 
food, and health facilities. From the hajiyat aspect, the family should fulfill the need of vehicle, communication equipment, and household ware as stove, refrigerator, and other equipments. Last, from the tahsiniyat aspect, if the family is living in prosperity, they should consider taking care of unproductive or old parents and ex-wife who has been divorced while she is pregnant, or if it is necessary to decorate the house living and buy some accessories (Syahatah, 1998).

\section{Intelligence Preservation}

A good family should be able to fulfill the needs of family member. From the aspect of dharuriyat, the family should comply with the need of education particularly for the children. This need is important to produce smart, strong, and pious generation (Hafidhuddin, 2007).

\section{Wealth Preservation}

There are some needs that should be complied with the family. From the aspect of dharuriyat, the family is obliged to allot some amounts of wealth to pay zakat, infaq, shadaqah, and wakaf. Then, if the surplus is still existed in the families' economy, this wealth had better save and make investment in order to be well distributed to the real and profitable sector of business. The inheritance might also be allotted as it is mentioned in Sharia, that the wealth had better distribute and manage in lawful business. From the aspect of hajiyat, the family is banned to do things that are illicit, like riba, gharar, risywah, corruption, bribe, thieving, and many others (Sahroni \& Karim, 2015).

\section{Lineage Preservation}

Marriage is a need for adult in a family, and then this need is categorized into dharuriyat. To fulfill this need the families do not only teach the children about the Islamic association, but also to prepare the children's future related to the marriage fund (Syahatah, 1998). 


\section{METHODS}

This research is categorized into case-study research. The case is the surrounding phenomena of moslem families in the highlight of economy aspect. The researcher exerts informants from the small moslem entrepreneurs in Malang under the criteria of small entrepreneurship asserted in Acts 20 of 2008 which mentioned that the small entrepreneur who has assets more than fifty millions up to five hundred millions and turnover more than three hundred million up to two point five billions. Those small entrepreneurs should be Islam and the business are managed and operated according to Sharia rules. The researcher collects the data through in-depth interviews, direct observations, and documentations.

Through those techniques of data collection, the researcher focuses to examine and investigate the phenomena of small moslem entrepreneurs including the characters and principles of Islamic economy. From these techniques, the researcher finds some concept development that is appropriate to the local wisdom, particularly Malang for the moslem families which is in accordance with Sharia principles. This research aims to solve the severity of modern lifestyle era which tends to set aside the characters and economic principles of moslem families from the original principles that have been determined in Islam.

\section{RESULT AND DISCUSSION}

Generally, the small moslem entrepreneurs in Malang are gathered in several communities as KPMI (Komunitas Pengusaha Muslim Indonesia), IIBF (Indonesian Islamic Business Forum), JPMI (Jaringan Pengusaha Muslim Indonesia), TDA (Tangan Di Atas), MTR (Masyarakat Tanpa Riba), SBC (Sukses Berkah Community), GBC (Grounded Business Community) and many other communities. From the observation result, here are eight informants that have been interviewed, and the data will be shown in the table below: 
Table 1. Profil of Informant

\begin{tabular}{|c|c|c|c|}
\hline No & Item & $\mathbf{N}$ & Percentage \\
\hline 1 & $\begin{array}{l}\text { Sort of Business } \\
-\quad \text { Culinary } \\
-\quad \text { Service } \\
-\quad \text { Commerce }\end{array}$ & $\begin{array}{l}3 \\
4 \\
1\end{array}$ & $\begin{array}{c}37,5 \% \\
50 \% \\
12,5 \%\end{array}$ \\
\hline 2 & $\begin{array}{l}\text { Age } \\
-\quad \text { Below } 25 \text { years old } \\
-\quad 25-35 \text { years old } \\
-\quad 35-50 \text { years old }\end{array}$ & $\begin{array}{l}0 \\
7 \\
1\end{array}$ & $\begin{array}{c}0 \% \\
87,5 \% \\
12,5 \%\end{array}$ \\
\hline 3 & $\begin{array}{l}\text { Sex } \\
-\quad \text { Male } \\
-\quad \text { Female }\end{array}$ & $\begin{array}{l}8 \\
0\end{array}$ & $\begin{array}{c}100 \% \\
0 \%\end{array}$ \\
\hline 4 & $\begin{array}{l}\text { Martial Status } \\
-\quad \text { Married } \\
-\quad \text { Single }\end{array}$ & $\begin{array}{l}8 \\
0\end{array}$ & $\begin{array}{c}100 \% \\
0 \%\end{array}$ \\
\hline 5 & $\begin{array}{l}\text { Number of Children } \\
-\quad 0 \\
-\quad 1 \\
-\quad 2 \\
-\quad 3 \\
-\quad<3\end{array}$ & $\begin{array}{l}1 \\
1 \\
2 \\
2 \\
2\end{array}$ & $\begin{array}{c}12,5 \% \\
12,5 \% \\
25 \% \\
25 \% \\
25 \%\end{array}$ \\
\hline 6 & 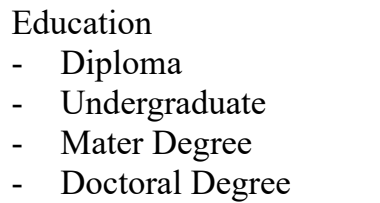 & $\begin{array}{l}3 \\
5 \\
0 \\
0\end{array}$ & $\begin{array}{c}37,5 \% \\
62,5 \% \\
0 \% \\
0 \%\end{array}$ \\
\hline 7 & $\begin{array}{l}\text { Omzet } \\
-\quad 500 \text { million }-1 \text { billion } \\
-\quad 1 \text { billion }-2,5 \text { billion }\end{array}$ & $\begin{array}{l}5 \\
3\end{array}$ & $\begin{array}{l}62,5 \% \\
37,5 \%\end{array}$ \\
\hline
\end{tabular}

Source: Processed Data (2018)

\section{Building Spiritual Values from the Economic Characteristics of Moslem Families \\ Iman as Principal Foundation of Economy}

The spiritual values seem to fade recently in the economic characteristics of moslem families. Then, it is absolute to build those values, since actually the economy of moslem families must be based on the Islamic principles to pursue and realize Maqashid Sharia practice. Fundamentally, iman becomes a self shield for the economy of moslem families. The moslem families 
should take care and improve their iman by any effort to keep consistent in worship. The worships are not only restricted solely to the owners who are the patriarch in their families, but also the owners should be able to influence and invite the employees to be able to realize that kind of worship as they have been tried to their own families.

To maintan iman, man should also pay attention to the source of their income and expenditure from the things that are illicit. The moslem families as small moslem entrepreneurs do consider to this point. Within the business management, they watch over the kind of business, selling goods, and raw materials. For instance, the small moslem entrepreneur who focused on culinary business, they surely paid attention to the lawful food compositions, cooking and production process, and serving manner. The small moslem entrepreneurs who are focused on chicken butchering and aqiqah, they considered to the way of lawful butchering of chicken and lamb according to the Sharia in order to watch over the lawful and good quality of meat. The small moslem entrepreneurs who are in service sector, they would not serve pre-wedding clients except families, photography class, and profile company, the moslem families do avoid to expend some funds that are prohibited in Islam like to help the strange funds that seemed as doubtful, except to expend some funds for the purpose of shadaqah to orphan children, poor families, mosque building and many other forms of funds that might bring good benefit to other human. In short, the moslem families prevent their selves from the activity of riba that mostly emerged in this modern era.

Moslem families regard that to honor the wealth they owned in lawful ways is a form of iman. The moslem families believe that the wealth is entrusted good, challenge, medium of worship, and instrument of dakwah. Entrusted good means that the wealth is tentative thing in this world and it would not be carried with us until akhirat. Challenge means that the way moslem families honor and manage the wealth, it indicates how good or bad they are. The wealth could be useful for not only the family member but also to the other human. Therefore, the wealth could be medium of worship and instrument of dakwah. As many as 
moslem families have much prosperity, the level of their iman ought to be higher. It means that they should be able to keep good heart, take care of self, have good character, improve worship and offer more shadaqah.

\section{Character Perfection is Based on Akhlaqul Karimah}

To have good character transforms the economy of moslem families to be perfect. By having good character, it would create harmony within the moslem families, relation with the employees, customers, suppliers, investors, and other human beings. The moslem families should have these characters: honesty, appreciation, professionalism, discipline, time appreciation, respectful, trusteeship, brotherhood, agreement, and contentment

\section{Lawful and Wholesomeness as Vital and Absolute Point}

For moslem families, the term of lawful means to prevent everything that seems to be illicit and doubtful like transaction of usury, improper butchering manner, pre-wedding service, and illicit or doubtful raw materials consumption. The term of wholesomeness means to prevent the ways that are banned in Islamic principles. Besides, the moslem families also should consider to the aspect of food consumption. It should be lawful and self-cooking if it is necessary, to minimize and avoid fast-food consumption, and prefer to by foods to the moslem groceries and restaurants. Lawful and wholesomeness is important point to the economy of moslem families, since lawful and wholesomeness is absolute and obligatory for the moslem. The purpose is to pursue the blessings of life from Allah Ta'ala. To be blessed means to have comfortable and happy life in the world and the day hereafter. The blessing from Allah is not only dedicated for individuals, but it is also useful for the family of employees, customers, suppliers, and other involved human beings. Moreover, lawful has good impact to the whole aspects of life as family's harmony, blessed wealth, generation and surrounding society. Lawful is not only measured from how the moslem families get and produce that wealth, but also how the quality of that wealth is produced and could be distributed for the benefits of other human being. 


\section{Scale of Priority as an Expenditure Reference}

To set priority in expenditure is important in order to manage the economy of moslem family. The scale of priority is divided into three significant things, they are: essentials, complementaries and embellishment. The moslem families should firstly prefer to the essential needs before coming to the other needs, since to fulfill this need is influential to the existence of life. Moreover, to fulfill this dharuriyat need is also based on the aspect of what moslem families need, it is not on what they want. First, the moslem families should fulfill essential needs as clothing, house, food, money for both the wife and children, toy for children, gift for wife, electronic tools, and many other. This level of need priority is relative, which means that each moslem family has their own ways to manage, but commonly they are as mentioned in previous explanation. This priority scale might be different because each moslem family has different level of economy and different stage of need compliance.

\section{Moderation as Absolute Standardization}

In this matter, balance means to balance between the income and expenditure and to prevent excessiveness, but it does not mean to be stingy and too thrifty. This balance means to buy consumptive goods without having any debt, instead to put some savings. It indicates that the moslem families are able to be thrifty. To be thrifty and economical does not mean to buy goods based on what the moslem families want, but to manage expenditure that are based on the need of families. Moreover, it also means to do not expend or buy goods excessively. Sometimes, it is allowed to buy some goods that they want as long as if it is necessary and does not tend to waste much fund.

However, to be thrifty is also based on the condition and situation of individual. If he owns much money and wants to buy branded cloth, it is permitted as long as the clothing expenditure is based on the need. The other example, if he intends to buy a car of high brand like Civic, Pajero Sport, and Fortuner under the condition that he really needs this kind of car because of having high class clients of corporate, while actually buying the car of 
aAvanza brand is enough. This kind of condition is sometimes permitted. The moslem families interpret the thrift does not mean to decrease the need, and if it possible to have some rest of money after the primary needs are completed, it is good to give charity to the poor, orphan, and to contribute in building the mosque and other social activities.

\section{Man's Responsibility is to Earn Money and Honor the Wealth Ownership of Woman}

Man as a husband is responsible to earn money and create good living. The husband who makes effort in earning money is one form of his ikhtiar to make living of his family, including his wife, children, and parent. This ikhtiar also means as a form of worship. From the money he earned from work, there are some rights of his wife, children, and parent to be shared and fulfilled. Then, it is obligatory to the husband to give their provision every month. When the husband gets some amount of inheritance, he should give the right of his wife and children. Inversely, if the wife is working, then the money she gets from work is absolutely for her. It is also happened when she gets some amount of inheritance; the husband is prohibited to take over the right of her wealth. However, the wealth ownership might be used in good and prospective ways like buying some assets (house, car, motorcycle, etc) under the communication and agreement between the husband and wife. Those are the form of how Islam honors the wealth ownership of woman. Each man and woman deserves to have each right.

\section{Internalization of Islamic Economy Principles in the Economy of Moslem Families}

The transition from traditional era to modern era affected to some temptations and challenges from every aspect of life that is able to alter the economy of moslem families seems to be conventional individualism, materialism, and consumerism. Therefore, it requires the internalization of Islamic economy principles in the economy of moslem families to be able realize the practice of Maqashid Sharia. 


\section{To Work is a Form of Ikhtiar and Worship}

From the result of working and running business, the moslem families acquire amount of money. Indeed, this money is regarded as blessing for the moslem families, but not all blessings are in the form of money. They utilize this income of money to useful things for their families and to help other human being. They define the blessing in wider meaning. It can be in the form of health, family's harmony, pious children, solid team or colleague, nice friend, time, intelligence, and so on.

To work is a form of ikhtiar for the husband to earn money and fulfill the family's need. Therefore, working becomes an obligation and worship for the moslem especially man to acquire the blessing from Allah. Besides, working also aims to fulfill the principal needs or economic need of family. It is also beneficial for other human being to help or open up job opportunities to the society to help them to earn money for families.

Working has its principles that have been regulated in the moslem families. One of them is that working is an obligatory for the husband as his effort and ikhtiar to fulfill the needs of family. Whereas, the wife has obligation to take care of households, to raise and take care of children, to keep the husband's honor, and also to be a first school for the children to learn every part of life aspects. This concept is in line with the theory which asserted that to earn money is an obligatory for the husband or patriarch of family, while to take care of household matters is an obligatory for the wife. Relating to this matter, the wife is permitted to work under certain circumstances and limitations. It is sunnah and permitted if the family is needed additional fund for family's need. By the condition that the wife must not leave the main duty of wife to manage and take care of everything related to the household. Moreover, the job should be appropriate to the woman's passion and feminism, have permission from the husband, do not gather in non-muhrim colleagues, do not show her beauty and rich, and work in the case of need situation. As fundamentally, to work is a duty for the husband in order to fulfill the need of family, wife, and children. Despite, the role of husband is quite significant in the family except his duty to work outside. The husband should be 
able to manage the time between working and having quality time with family. Since, the role of husband existence could be positive effect to the family's life in the future. This second duty aims to build harmony between the husband and wife, to be role figure for the wife and children, to teach religious education to the children, to share positive values to the children, and many others. Further, it is good to take care of the unproductive and old parents as our devotion to every kindness that the parents have given and raised us. To respect and take care of the parents could open another door of blessing to the family. To work is one of professions which Allah has promised for the human to open up the nine doors of blessing. Indeed, the work should be in lawful and good manners according to the Islamic principles. For example, the photography service should not serve pre-wedding, doubtful photo sessions or sexy model customers, culinary businessman should observe the food composition, material, process, and serving.

\section{Expenditure as Wealth Distribution in Material and Spiritual}

The wealth that are produced from work should be useful for the family to fulfill the basic needs on the material and spiritual scale. Generally, moslem families divide the expenditure into three parts, they are consumption, donation, and investment. The expenditure itself has the principles to apply to the economy of moslem families.

\section{Consumption Standardization}

From the result of work and business, the income would be used to fulfill the need of moslem families. To fulfill the need of family, wife, and children is an obligation of husband based on the income he could obtain from work. If it still lacks of principal needs, the wife and children ought to give motivation and encourage the husband, and also to pray to Allah to shower them with unstoppable blessing. The rest money could be used to take care of the unproductive old parents, since they have already too old to work and earn money for life. This is counted as wajib for the son to take care of the need of his parent as long as he is able to cope with the financial matters. To take care of the parents 
is a form of devotion which could open up wider opportunity of blessing.

Wife is allowed to work under certain circumstances and limitations in the purpose of helping the economy of family to fulfill the primary needs. However, it is sunnah and only considered as an additional income in the family. The wife should be able to manage the financial budget in family's need and amanah to carry out her duty as housewife. The husband might give some advices and suggestions to help the wife considering and deciding the expenditure budget of family's principal needs.

To buy the family's need should be adjusted to the list of need. The expenditure of family's need should be adjusted to the things what they really need and not to what they want. This basic idea is good to remember to maintain the balance between the income and expenditure in the economy of moslem families. If the member of family wants to buy something which is not really urgent and vital, then, it is better to save the money patiently. If the need is really urgent, he could borrow some amount of money to the family member, take some money from the savings, trade some assets, or take some credits to the institution of Sharia banking. This extra expenditure is adjusted to the condition of family and considered as the last alternative. It is safer to buy goods in cash. If it is needed, the debt is should not be used to the consumptive goods, but to use it for the productive activity of business. This strategy could balance the income and expenditure.

To make sure that the income of moslem family is obtained from lawful manners is important. The moslem families should prevent their selves from illicit and doubtful, for instance the food they are consuming every day should not contain pork and other illicit or doubtful compositions. Also, the moslem families ought to avoid being show off and prestige in the expenditure of food consumption. They should minimize and avoid buying fast-food or decrease to buy foods which are produced by nonmoslem, particularly when it is still uncertified as lawful foods. Lawfulness and wholesomeness would have impact to the health of family, while illicit foods in vice versa. 
It is significant to firstly put priority on the essential needs before coming to the complementary needs and tahsiniyat. The moslem families should distinguish between the need and want. They have to fulfill the essential need such as clothing, house living, food, need of wife and children, need of parents, charity, employee's salary, educational fund and other monthly needs in family. If the moslem families already fulfilled the essential needs, they might fulfill the other needs like family's vacation, children's toy, wife's gift, electronic tools, etc. The priority level of this need is relative, which means that each family has their own way to manage this need expenditure. The level of dissimilarity is based on the fact that each family has different level of economy and different stage of need.

To manage the expenditure should be plain. The plain does not mean to be miserable, but to manage the expenditure as it is needed for the family. The plain need here does not mean to avoid buying the branded goods, but firstly to consider the situation and condition. Moreover, buying the branded goods is for the purpose of family's need. It is not allowed buy them in order to show off the prestige, lifestyle, and the wealth. The moslem families buy the goods in accordance with the functions, benefits, and maslahah, since to be too over and extravagant in the expenditure tends to be mubazdir, meaningless, and wasting money. They also should be thrifty and economical as long as the principal need of family is fulfilled and know how to benefit the wealth in good things for other human beings.

\section{Donation as a Realization of Social Wealth Principle}

Donation transformed to be an obligatory and need of family. The moslem families agree that some of their wealth are belonged to other human being. Due to the fact that they regard and motivate their selves that to give shadaqah would shows them with more blessing, tranquility, and benefit to human interest. Shadaqah does not only refer to money, but also to give some useful goods for the other human interest. Zakat, infaq, and shadaqah are means to minimize and omit the discrepancy between the rich and poor human being, in order to build harmony in society. 
If the wealth has reached to nisab, it is a must for the moslem families to give zakat from the income about $2,5 \%$. If the amount of wealth does not reach this percentage, it is called shadaqah and infaq. The moslem families target the donation in approximately $2,5 \%, 5 \%, 10 \%$, up to $20 \%$. Commonly, the donation is given in every month and distributed to the organization of zakat, to donate mosque building, or orphanage for the orphan and poor people. They are also able to give shadaqah by lending their assets like to donate the car to be utilized in the need and interest of dakwah and other Islamic activities.

\section{Investment as Wealth Enrichment}

The moslem families needs to know the importance of investment, since Islam prohibited the wealth ownership which remain to be unproductive and undeveloped. The investment is useful in both long and short-term necessity. The investment is classified in several forms: 1) the investment of assets purchase is able to improve the business. 2) the investment of gold and land ownership. 3) the investment in business capital sharing. 4) the investment of agriculture capital sharing. 5) the investment of building a cottage for guests in Islamic boarding school. 6) the investment of science. Further, it is also important to consider lawful and illicit in every aspect of doing investment.

\section{Savings as Urgent Post of Future}

The good moslem families should set aside a portion of wealth to be saved and used in the future needs. The savings is divided into two urgent posts, business post and family post. It aims to capitalize the business in long term by restraining the profit, and then it could be useful for the future or urgent needs of family as fund of health, disaster, qurban savings, asset purchase savings, and future funds of education or marriage for children.

\section{Wealth Ownership as Instrument of Worship to Allah}

Ownership could be represented through its meaning of wealth. By the wealth ownership, the moslem families are able to do activities of consumption, distribution, production, and 
investment. The hardest activity of ownership is the activity of distribution. This matter is regarded as the real ownership of wealth, which means how the moslem families could distribute the wealth they owned to contribute and give benefit to the human interest. From this activity, the wealth ownership becomes a medium for the moslem families to devote and worship to Allah. To note that the wealth is temporary goods and it is better to make it an instrument for the owner to help interests of dakwah. It is a form of devotion from the moslem families to make use their wealth more beneficial to other human being.

Furthermore, the wealth ownership is represented through separation between the property right of man and woman. If the woman is working, then the property is absolutely belonged to her. The man is obliged to work, and the property is not only belonged to him, but also belonged to the family members to fulfill the needs of them. Nowadays, to merger the property between the husband and wife is fair in the condition of both of them have already communicated and well considered to this idea. According to Islamic principle, this merger is allowed as a form of trusteeship, amanah and love between the husband and wife. The inheritance might also be the source of property ownership for moslem families in the form of house.

\section{Maqashid Sharia as the Measure of Moslem Families Economy in the Era of Modern Lifestyle}

In accordance with the economy of moslem families, they should be able to fulfill the need by realizing common good and prevent from harm. Then, the principle of Maqashid Sharia would be guidance and standardization to maintain the economic activity of moslem families in Sharia principles and to implement kulliyat al-khamsah.

\section{To Protect Religion}

To protect religion, the moslem families should maintain their worship. This realization is a form of consequence from the moslem to protect the religion and faith. Moreover, it is not 
simply as an individual practice to protect the religion, but also to invite and keep the practice of worship to the family members and employees. Every activity should be based on the principles of Al-Qur'an and Hadits. Worship could build the moslem families' character to be good character human being with iman, muamalah, and akhlaq.

Moreover, the moslem families should observe lawful and illicit in every aspect of life and prevent the family from illicit and doubtful things. This could be reflected from the profession, sort of business, selling goods, process and production, and income of the moslem families. Further, to consume lawful foods and avoid fast-food and other doubtful foods, also to prevent consumption from uncertified restaurant as they are lawful according to MUI. Besides, within the investment, they should observe lawful and illicit to prevent from usurious transaction, clear agreements between collaboration parties of moslem.

\section{To Protect Soul}

Soul protection is represented from how the moslem families fulfill the principal need of family, since this matter refers to their existence of life. If the principal needs are not fulfilled, it would cause threat, breakage, and trouble in the existence of life. Regarded to this impact, the moslem families must set priority on need. The wealth should be utilized in useful things for the moslem families.

The moslem families should firstly put priority on the essential needs comprising of the need of clothing, house living, food, need of wife and children, need of parents, zakat and shadaqah, employee's salary, educational fund and other monthly needs in family. If the moslem families already fulfilled the need of dharuriyat, they might fulfill the other needs like family's vacation, children's toy, wife's gift, electronic tools, etc. The priority level of this need is relative, which means that each family has their own way to manage this need expenditure. The level dissimilarity is based on the fact that each family has different level of economy and different stage of need. 


\section{To Protect Intelligence}

To realize the intelligence protection in the economy of moslem families, they should prepare for the educational fund of children. They should prepare and teach the children to be the future generation of rabbani. Therefore, the need of educational fund becomes important for the moslem families. Moreover, they should look for the Islamic school which is able to guide and teach the children spiritually and scientifically. Above of all, the role of parent is quietly vital to be their children's first school in the home. The knowledge and science would build and characterize the children to have a good intelligence and moral. Therefore, it is important to make sure that the children acquire Sharia doctrines in the school.

Besides, it is also significant for the parent to upgrade both scientific and Islamic knowledge. This strategy aims to prevent the moslem families from the thought and concept which is out from the principles of ilahiyah in Al-Qur'an and Hadits. To pursue this aim, the moslem families could live in the Islamic environment, associate with good people, move from the evil environment, be active to pray together in mosque, and many other ways. If the moslem families have status as the owner of business, they should invite the employee to pray and worship, and also to upgrade their knowledge through some routine recitations of dakwah.

\section{To Protect Wealth}

The moslem families who work in business and entrepreneurship are promised to have one of nine doors of blessing from Allah. From every sort of business, the moslem families should observe their property source, consumption, and distribution in lawful and prevent them from illicit things. This concept is absolutely for the good moslem families. For the moslem families, the term of lawful means to prevent everything that seems to be illicit and doubtful like utilizing doubtful raw materials and compositions, improper butchering manner, and pre-wedding service. Moreover, to purify and make use of the property, the moslem families should distribute some of their income about $2,5 \%$ to $20 \%$ to the mustahiq of zakat. Also, it is good 
to invest the property in productive and prospective business as long as the business is utilized and distributed in lawful manners, like the investment of gold, land, capital sharing of business and agriculture.

\section{To Protect Generation}

To protect the generation of moslem families, they should realize and make some saving posts for their children's future need, marriage funds. Actually, this post of saving is not only used as this single purpose, but also to cover the post of disaster, education, urgent needs, qurban, and infaq. Besides, to make some savings post, the moslem families could also fulfill those needs through the result of investment, since the investment is always improving and particularly beneficial to the long-term period of time.

\section{CONCLUSION}

Modern lifestyle has great impact to the economy of moslem families. To come over this situation, the moslem families should hold the Sharia principles as mentioned in Al-Qur'an and Hadits. This kind of economy could deliver positive impact, peacefulness, and harmony within the moslem families. Besides, to realize the happier life, the moslem families could help the human interest and improve the prosperity of society. To build good economy, the moslem families should realize the economy according to the characteristics and principles of Islamic economy. The characteristics of moslem families economy comprise of Iman as basic foundation of economy, character perfection of akhlaqul karimah, lawfulness and wholesomeness which are vital and absolute thing to consider, scale of priority as the expenditure reference, moderation as absolute standardization, man's responsibility to fulfill the need of family, and wealth honor of woman's ownership. The internalization of Islamic economy principles in the economy of moslem families covers the concept that to work is a form of worship and ikhtiar, to expend as a form of wealth distribution materially and spiritually, to save money for the future urgent posts, and to regard the wealth as an instrument 
to devote to Allah. As for, the principles of Islamic economy in the economy of moslem families covers the idea that to work is a form of ikhtiar and worship, to expend as a form of wealth distribution in either material or spiritual, to save money for the future urgent posts, and to value the wealth as an instrument to devote to Allah. Above all, to realize the practices of Maqashid Sharia, the moslem families should protect the religion as their consistency of worship and to protect their income and expenditure from illicit and doubtful, protect the soul and fulfill the principal need of family, protect the intelligence by saving some funds for education and upgrading Islamic knowledge and view, protect the generation by saving some funds for future needs, for instance marriage, education, and health.

\section{REFERENCES}

Aziz, Abdul. (2013). Etika bisnis perspektif Islam. Bandung: Alfabeta

Alfitri. (2007). Budaya konsumerisme masyarakat perkotaan. Majalah Empirika, 9(1).

Bungin, Burhan. (2012). Metode penelitian kualitatif: komunikasi, ekonomi, kebijakan politik, dan ilmu sosial lainnya. Jakarta: Rajawali Pers

Chaney, David. (2004). Lifestyle sebuah pengantar komprehensif. Yogyakarta: Jalasutra

Diana, Ilfi Nur. (2011). Hadis-hadis ekonomi. Malang: UINMaliki Press

Djalaluddin, Ahmad. Belanja barakah. http://www.tazkiyatuna. com/belanja-barakah/retrieved on 20 January 2018

Djalaluddin, Ahmad. (2018). Ekonomi keluarga muslim: menabung. Telegram retrieved on 20 January 2018

Hafidhuddin, Didin. (2007). Agar harta berkah dan bertambah. Jakarta: Gema Insani

Hendariningrum, Retno dan Susilo, Edy. Fashion dan gaya hidup: identitas dan komunikasi. Jurnal Ilmu Komunikasi, 6(2).

Ibn Khaldun. (2013). Mukaddimah. Jakarta: Pustaka Al-Kaustar K. Yin, Robert. (2014). Studi kasus: desain \& metode. Jakarta: PT. Raja Grafindo Persada 
Kara, Muslimin. (2012). Pemikiran al-syatibi tentang maslahah dan implementasinya dalam pengembangan ekonomi sharia. Assets, 2(2).

Moleong, Lexy. 2014. Metode penelitian kualitatif. Bandung: PT. Remaja Rosdakarya.

Mustofa, Imam. (2008). Keluarga sakinah dan tantangan globalisasi. Al-Mawarid 13.

Nueman, Lawrence. (2016). Metode penelitian sosial: pendekatan kualitatif dan kuantitatif edisi 7. Jakarta: Indeks

Nurdiani, Nina. (2012). Teknik sampling snowball dalam penelitian lapangan. comtech, 5(2).

Purhantara, Wahyu. (2010). Metode penelitian kualitatif untuk bisnis. Yogyakarta: Graha Ilmu

Syahatah, Husein. (1998). Ekonomi rumah tangga muslim translated from its original Iqtishadil Baitil muslim $f i$ dau'isy syari'atil-Islamiyyah. Jakarta: Gema Insani

Sahroni, Oni dan Karim, Adiwarman. 2015. Maqashid sharia \& keuangan islam. Jakarta: PT. Raja Grafindo Persada

Syarifuddin, Amir. (2008). Ushul fiqh. Jakarta: Kencana Prenada Media Group

Sugiyono. (2016). Metode penelitian kuantitatif, kualitatif, dan $R \& D$. Bandung: Alfabeta

Shidiq, Ghofar. (2009).Teori maqashid sharia dalam hukum Islam. Sultan Agung, 44 (10). 